\title{
PLANTS IN FAMILY LAMIACEAE USED MEDICINALLY IN THE HOMOEOPATHIC SYSTEM FOUND IN THE NILGIRIS DISTRICT, TAMIL NADU, INDIA
}

\author{
MUGENDHIRAN $\mathbf{S}^{\mathbf{1}}$, SHASHIKANTH J ${ }^{1}$, MURALI $\mathbf{M}^{1}{ }^{1}$, RENU ARYA ${ }^{2}$, RAJAN $\mathbf{S}^{1}$, ANIL KHURANA ${ }^{2}$
}

${ }^{1}$ Centre of Medicinal Plants Research in Homoeopathy, Indira Nagar, Emerald, The Nilgiris, Tamil Nadu, India. ${ }^{2}$ Central Council for Research in Homoeopathy, 61-65, Institutional Areas, Opp. D-Block, Janakpuri, New Delhi, India. Email: mugendhiranselvamm@gmail.com

Received: 22 November 2019, Revised and Accepted: 03 February 2020

\section{ABSTRACT}

Objective: The objective of the present study was to survey and document homeopathic medicinal plants in Nilgiris District, Tamil Nadu, India.

Methods: To collect homeopathic plants of Lamiaceae in the Nilgiris District, we undertook various field trips during the year 2018-2019. The plants collected were pressed, poisoned, mounted, and stitched on herbarium sheets and deposited at the Centre of Medicinal Plants Research in Homoeopathy herbarium (Acronym SMPRGH).

Results: The present study deals with both wild and cultivated species of 15 genera belonging to 24 species of Lamiaceae family members reported in the Nilgiris District. Reported homeopathy plants such as Aloysia citriodora Palau, Lavandula officinalis Chaix., Leonurus cardiaca L., Leucas aspera (Willd.) Link., Mentha piperita L., Mentha spicata L., Melissa officinalis L., Mesosphaerum suaveolens (L.) Kuntze, Ocimum americanum L., Ocimum basilicum L., Ocimum gratissimum L., Ocimum tenuiflorum L., Origanum majorana L., Origanum vulgare L., Perilla frutescens (L.) Britton, Plectranthus amboinicus (Lour.) Spreng, Plectranthus barbatus Andrews, Plectranthus fruticosus L'Her., Prunella vulgaris L., Rosmarinus officinalis L., Salvia officinalis L., Salvia verbenaca L., Thymus vulgaris L., and Thymus serpyllum L., the present article gives the scientific name, synonym, homeopathic drug name, original author citation, English name, phenology, short description, and part of plant used for preparing homoeopathic medicine, whether indigenous or exotic and uses are given.

Conclusion: Reported 24 homoeopathic medicinal plants are used in homoeopathic medicinal system to treat various diseases, and also present study reveals the importance of conservation and sustainable utilization.

Keywords: Lamiaceae, Homoeopathy, Medicinal plants, Nilgiris, Tamil Nadu.

(C) 2020 The Authors. Published by Innovare Academic Sciences Pvt Ltd. This is an open access article under the CC BY license (http://creativecommons. org/licenses/by/4. 0/) DOI: http://dx.doi.org/10.22159/ajpcr.2020.v13i4.36450

\section{INTRODUCTION}

Homeopathy is one of the alternative systems of medicines having a well-documented pharmacopeia [1]. Herbal medicines have been used for many years dating back to $3000 \mathrm{BC}[2,3]$. The codified traditional systems of medicine such as Ayurveda, Unani, Siddha, and Homoeopathy and unmodified traditional system such as the documentation of medicines used by various tribes have now become quite popular in India. About $2 \%$ of people in the United Kingdom and the United States use homeopathy in any 1 year, while it is about $15 \%$ in India, where it is considered part of Indian traditional medicine. This system of medicines relies mainly on plants and mineral components as a drug [1]. The Nilgiris hills form a well-defined plateau situated at the junction of the two great ranges of hills bordering the Deccan, peninsula, namely, the Eastern and Western Ghats. The Nilgiris lies between $11^{\circ} 12^{\prime} \mathrm{N}$ and $11^{\circ}$ $43^{\prime} \mathrm{N}$ and $76^{\circ} 14^{\prime} \mathrm{E}$ and $77^{\circ} 1^{\prime} \mathrm{E}$. The district has diverse habitats for the growth of various indigenous and exotic medicinal plants used in homoeopathic system [4]. Homeopathy system of medicine is based on two basic natural principles, "similia similibus curentur" or "let likes be cured with likes" which means a drug can cure that (symptoms) which it can produce in a healthy human body by a unique process known as proving and second - "law of minimum dose" - the notion that "lower the dose of the medication, the greater its effectiveness." Homeopathic doctors consider all mental, physical, and emotional aspects of the patient. More than 30,000 plant specimens of medicinal importance are grown all over the world, but only around 2500 plant species are known to be useful for homoeopathic medicine preparation. Over 600 plants are now routinely used as drug sources in homeopathy [5]. The alternative medical system of homeopathy was developed in Germany at the end of the $18^{\text {th }}$ century. In India, homeopathy is one of the important systems of medicine. The market is growing at $25 \%$ a year, and more than 100 million people depend solely on this form of therapy for their health care. Around $10 \%$ of India's population depends solely on homeopathy for their health care. Homeopathic remedies are derived from six major sources such as plants, minerals, animals, diseased tissues, hormones, and healthy tissues and imponderables. The present topic deals only with angiosperm plants, a part of the plant kingdom of the family Lamiaceae. According to homeopaths, serial dilution, with shaking between each dilution, removes the toxic effects of the remedy while the qualities of the substance are retained by the diluents (water, sugar, or alcohol). The end product is often so diluted that it is indistinguishable from pure water, sugar, or alcohol. Practitioners select treatments according to a patient constitution that explores the physical and psychological state of the patient, both of which are considered important for selecting the remedy [6-8]. The Lamiaceae family consists of 69 genera and 425 species in India. Plants of Lamiaceae family are known for their essential oils [9]. Many active essential oils have been isolated from members of this family. This family is also famous for the presence of diterpenoids among its members. The Lamiaceae species are important for their antimicrobial properties which are used in research, for instance, Salvia argentea L, Stachys annua L, Ballota nigra $\mathrm{L}$, and Melissa officinalis L, among others [10]. Lamiaceae species have provided important resources for the old and new world and their use in medicine and as condiment in regional cuisine is of central importance for instance in countries such as Turkey, China, Middle East countries, India, Brazil, and Egypt, among others [10-12]. Herbal medicines are regarded as effective and promising sources of potential neuroprotective agents because of their cognitive benefits and more significantly, their mechanisms of action with respect to the fundamental path of physiology of the diseases. Review has acknowledged 
several herbal medicines such as such as $M$. officinalis, Ocimum sanctum, Rosmarinus officinalis, and Salvia officinalis with potential therapeutic effects for neurodegenerative diseases [13]. Lamiaceae family includes numerous known species that are used as traditional medicine. The general aspects, traditional uses, pharmacology, and in vitro and in vivo studies of Betonica officinalis, Glechoma hederacea, Hyptis pectinata, Lavandula spp., Leonurus cardiaca, Lamium spp., $M$. officinalis, Mentha spp., Marrubium vulgare, Origanum spp., Ocimum spp., R. officinalis, Salvia spp., Satureja hortensis, Stachys lavandulifolia, Scutellaria lateriflora, Sideritis spp., Teucrium spp., Thymus spp., and Ziziphora tenuior belonging to Lamiaceae botanical family reported that the medicinal plants have potent analgesic and antinociceptive activity and new potential therapeutic agents [14]. Documentation of Lamiaceae family used as homoeopathic system of medicine in Nilgiris District. Totally, 24 plant species used in homoeopathic medicine from Lamiaceae are described and discussed.

\section{METHODS}

The Nilgiri District in Tamil Nadu is part of the Western Ghats and lies between $11^{\circ}, 12^{\prime}$ and $11^{\circ}, 43^{\prime} \mathrm{N}$ and $76^{\circ}, 14^{\prime}$ and $77^{\circ}, 1^{\prime} \mathrm{E}$ in the north of western part of Tamil Nadu [15]. The Nilgiri Biosphere Reserve is an International Biosphere Reserve and occupies a total area of $2542.49 \mathrm{~km}^{2}$, located in the Western Ghats of Palghat Gap $\left(10^{\circ} 45^{\prime}-12^{\circ}\right.$ $5^{\prime} \mathrm{N}$ latitude and $76^{\circ} 10^{\prime}-77^{\circ} 10^{\prime} \mathrm{E}$ longitude), spreads over an area of $5520 \mathrm{~km}^{2}$ in the states of Karnataka $\left(1527.4 \mathrm{~km}^{2}\right)$, Kerala $\left(1455.4 \mathrm{~km}^{2}\right)$, and Tamil Nadu $\left(2537.6 \mathrm{~km}^{2}\right)$. The total geographical area of sholas in Nilgiris is 4225 ha (Fig. 1).

During the present study, regular field trips were made from June to May during the year 2018 to 2019 and collected 24 plant species of Lamiaceae family. All the collected plant specimens pressed, poisoned, and mounted on herbarium sheets, herbarium specimens are prepared by standard methodology [16]. Plant species were identified with the help of regional floras [17-24]. Medicinal uses reported with the help of Materia Medica's [25-30].

The importance of the collection of cultivated plants both as exsiccatae for herbarium purposes and maintenance of germplasm collections in research gardens in situ as been reviewed elsewhere [31]. The herbarium sheets of these plants have been deposited in the herbarium of Centre of Medicinal plants Research in Homoeopathy at Emerald Acronym SMPRGH, The Nilgiri District, Tamil Nadu under CCRH, Ministry of AYUSH [32]. All the plants are useful in the homeopathic system of medicinal, as indicated by the part used and brief clinical indication. The enumeration, it is hoped, will be useful to pharmacognostic research workers in Botany as well as the practicing physicians of homeopathy. The nomenclature has been brought up to date and where ever necessary the synonyms appearing in homeopathic books, journal, have also been cited together with the plant names.

\section{RESULTS AND DISCUSSION}

India has seven national medical systems (Ayurveda, Yoga, Naturopathy, Unani, Siddha, Allopathy, and Homoeopathy), of which one of India's important health therapies is homeopathy. About 2500 plant species are known to be useful for medicinal preparations of different kinds in homoeopathy. Over 600 plants are now regularly used drug sources in homeopathy. Many of the drugs yielding plants are currently cultivated in India as well as some are procured from wild sources also. A checklist of 24 plant species used in homeopathic medicine from Lamiaceae is described and discussed. The present study deals with both wild and cultivated species with 15 genera belonging to 24 species of Lamiaceae family. The maximum number of genus has been recorded from the genus Ocimum (four species), followed by Plectranthus (three species), Mentha, Salvia, and Thymus and Origanum (two species), and in the rest of this studies each one species such as Aloysia citriodora, Hyptis suaveolens, Lavandula officinalis, Leucas aspera, Leonurus cardiaca, M. officinalis, Perilla frutescens, Prunella vulgaris, and R. officinalis (Table 1). Among the above plants, Perilla frutescence is first reported from Nilgiris as a homeopathic medicinal plant as well as a new record to Nilgiris.

Homeopathic medicine is very essentially an individualistic treatment than the other systems of medicines. Medicinal uses of plants have been discussed in great detail either in the Ayurvedic system [33] or by various tribal groups', i.e., ethno medico botany $[34,35]$. The studies on the use of plants in homeopathic system are rather scarce due to lack of interest in these systems in India in earlier days and overshadowing of homeopathic system by the revival of interest in the Ayurvedic System of medicine throughout the world in recent times [36]. Homeopathic therapy is very popular among the people of India and abroad because it is very cost effective and curative treatment from their origin, and it has no side effects in the human body. Therefore, this therapy is gradually increasing throughout the world, including in both developing and developed countries. Every civilization has developed indigenous medicinal systems to treat or cure diseases with the help of locally available materials. The age old experience of 1000 years in medical therapy has made these systems more reliable. The majority of the population trusts the

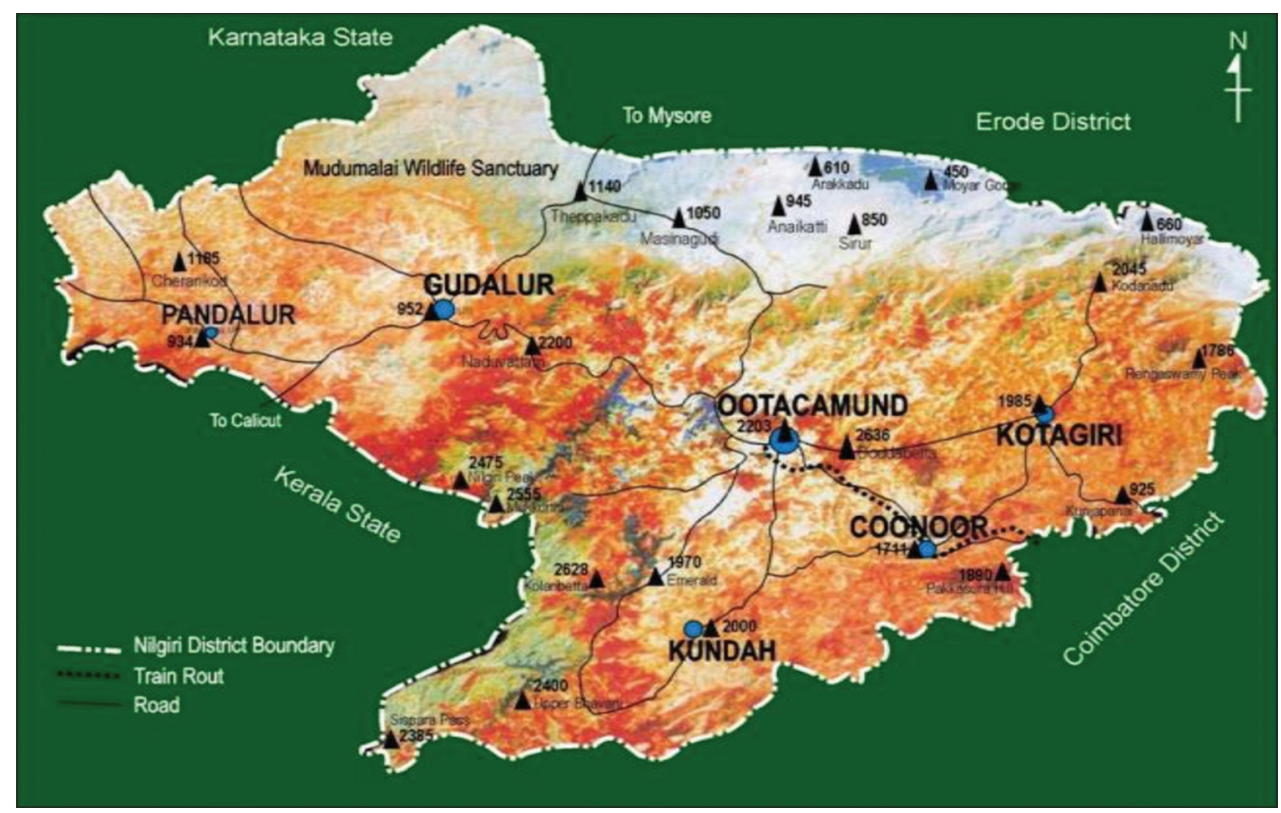

Fig. 1: Satellite map of the Nilgiris district with their altitude range 
Table 1: Quantitative analysis of the Lamiaceae plants

\begin{tabular}{lll}
\hline S. No. & Genus & No. of species \\
\hline 1. & Ocimum & 4 \\
2. & Plectranthus & 3 \\
3. & Mentha & 2 \\
4. & Salvia & 2 \\
5. & Thymus & 2 \\
6. & Origanum & 2 \\
7. & Hyptis suaveolens & 1 \\
8. & Lavandula officinalis & 1 \\
9. & Leucas aspera & 1 \\
10. & Leonurus cardiaca & 1 \\
11. & Lippia citriodora & 1 \\
12. & Melissa officinalis & 1 \\
13. & Perilla frutescens & 1 \\
14. & Prunella vulgaris & 1 \\
15. & Rosmarinus officinalis & 1 \\
\hline
\end{tabular}

traditional medicinal systems over allopathic system due to its lesserknown health implications. Among the traditional medicinal systems; Indian, Chinese, Arab, and African systems are world renowned [37].

\section{Enumeration}

Botanical Name: Aloysia citriodora Palau

Synonyms: Lippia citriodora (Palau) Kunth., and Verbena triphylla L'Her. Drug name: Lippia citriodora

English name: Lemon verbena, Lemon bee brush

Part used: Leaf

Uses: Asthma, Antifungal Property

Flowering and fruiting: June-September

Description: Native from tropical America, it is an herb with a semihardy stem, upright bushy, pale green narrow-leafed foliage, and small sprays of white flowers.

Botanical name: Lavandula angustifolia Mill.

Synonyms: L. officinalis Chaix., and Lavandula vulgaris Lam.

Drug name: Lavender

English name: Common lavender

Part used: Flowering tops

Uses: Anxiety, fungal infection, hair loss, depression, and high blood pressure, and wound.

Flowering and fruiting: May-August

Description: It is a perennial evergreen dwarf shrub, it has dense form and grey-green to green foliage. Its leaves are simple, slightly tomentose, and linear to lanceolate-linear up to $5 \mathrm{~cm}$. Its numerous verticillaster flowers appear on terminal spikes and are purple in color.

Botanical name: Leonurus cardiaca L.

Synonyms: Lamium cardiaca (L.) Bail., and Cardiaca vulgaris Moench.

Drug name: L. cardiaca

English name: Motherwort

Part used: Tincture of fresh plants

Uses: Dysentery, Hemorrhages, and miscarriage

Flowering and fruiting: July-September

Description: Herbs with quadrangular stem, which is clad in short hairs and is often purplish, especially near the nodes. The opposite leaves have serrated margins and are palmately lobed with long internodes. Flowers are pink to lilac in color often with furry lower lips.

Botanical name: Leucas aspera (Willd.) Link.

Synonyms: Leucas dimidiata Benth., and Phlomis aspera Willd.

Drug name: L. aspera (Drona)

English name: Thumba, and common leucas

Part used: Whole plant including roots

Uses: Asthma, cough and sneezing, antifungal, prostaglandin inhibitory, antioxidant, antimicrobial, antinociceptive and cytotoxic activities, antipyretic, and reduce fever.

Flowering and fruiting: September-January
Description: It is an erect or diffuses much branched annual herb, up to $50 \mathrm{~cm}$, leaves linear or narrowly oblong-lanceolate, very dense, many flowered with white color, the stems hispid, or scab rid.

Botanical name: Mesosphaerum suaveolens (L.) Kuntze

Synonyms: Hyptis suaveolens (L.) L'Her. Ballota suaveolens L.

Drug name: $H$. suaveolens

English name: Bush mint, and mint weed

Part used: Whole plant

Uses: Stimulant, carminative, and uterus affection

Flowering and fruiting: August-February

Description: A gregarious undershrub. Stem quadrangular, hairy, leaves aromatic, ovate, tomentose, pale green, turn into purplish green. Calyx tube larger, hairy, and persistent in verticillaster inflorescence.

Botanical name: Melissa officinalis L.

Synonyms: Faucibarba officinalis (L.) Dulac., and Thymus melissa E.H.L. Krause

Drug name: $M$. officinalis

English name: Lemon balm, and sweet balm.

Part used: Aerial parts

Uses: Anti-anxiety, sleep, digestion, pain relief, appetite and headache, antiviral property

Flowering and fruiting: June-August

Description: It is a perennial herbaceous plant 1-3 $\mathrm{m}$ tall, branched occasionally or too frequently with ascending to erect leafy stems. Individual flowers each flower has white corollas, a light green calyx; small nut-lets are lanceoloid-ellipsoid and smooth.

Botanical name: Mentha piperita $\mathrm{L}$.

Synonyms: Mentha balsamea Willd., and Mentha officinalis Hull.

Drug name: Mentha piperita

English name: Pepper mint

Part used: Whole Plant

Uses: Cough, dry, headache, hoarseness, influenza, pruritus, throat, and sore

Flowering and fruiting: July-August

Description: Native to Europe. It is an aromatic perennial herb, producing creeping stolon. The stem is quadrangular, hairy, and branching toward the tops. Leaves are opposite dark in color, flowers purplish in color.

Botanical name: Mentha spicata L.

Synonyms: Mentha glabra Mill., and Mentha crispa L.

Drug name: Mentha viridis

English name: Spear Mint, and Garden mint

Part used: Whole plant

Uses: Digestion problem, reduce heart problem, stomach problem, nausea, flatulence, anxiety, and body freshener.

Flowering and fruiting: July-August

Description: It is a perennial herb. The central stem and any lateral stem, four angular and glabrous, individual flower, calyx is light green to reddish-green and glabrous, while the corolla is white to light pink, small nut-lets that are located within the persistent calyx.

Botanical name: Ocimum americanum L.

Synonyms: Ocimum album Roxb., and Ocimum canum Sims.

Drug name: 0 . canum.

English name: Common basil, sweet basil, and hoary basil

Part used: Fresh leaves

Uses: Leave paste used to treat skin disease, coughs, respiratory problems, rheumatism, diarrhea, kidney, and renal colic, and its also applied to wounds.

Flowering and fruiting: Throughout the year

Description: Native to Africa, it is an erect, much-branched strongly aromatic under shrub, leaves are elliptic-oblong, ovate-lanceolate, glabrous margin entire or shallowly serrate, and flowers white with pedicels, fruit is nut-let. 
Botanical name: Ocimum basilicum L.

Synonyms: Ocimum hispidum Lam., and Ocimum thyrsiflorum L.

Drug name: Basilicum.

English name: Sweet basil

Part used: Whole plant

Uses: Clear the eyes, and bath tonic

Flowering and fruiting: Throughout the year

Description: A short herbaceous plant, strongly aromatic. Leaves are ovate-lanceolate, cuneate at base, pubescent or glabrous, floral leaves and bracts are usually dark purple in flower, nut-lets mucilaginous when wetted.

Botanical name: Ocimum gratissimum L.

Synonyms: Geniosporum discolor Baker., and Ocimum zeylanicum Medik. Drug name: O. gratissimum (Ram tulsi).

English name: Wild Basil, Shrubby basil; Tam: Ram Tulsi; and Hindi: Ban Tulsi.

Part used: Whole plant

Uses: Vomiting, skin disease, inflammation, antifungal, hypoglycemic, anti-diarrheal, increase sexual behavior activity, and analgesic

Flowering and fruiting: August-December

Description: A much-branched aromatic subshrub up to $4 \mathrm{~m}$ high.

Leaves are membranous ovate to elliptic-obovate, pubescent on the nerves above, much-branched the flowers pale greenish-yellow, nutlets is yellowish-brow, subglobose, and minutely verrucose.

Botanical name: Ocimum tenuiflorum L.

Synonyms: O. sanctum L., and Ocimum tomentosum Lam.

Drug name: $O$. sanctum

English name: Sacred basil, and holy basil

Part used: Whole plant

Uses: Asthma, cough, cold, catarrh, fever, period problem, bedwetting, diarrhea, abdominal symptoms, teary eyes, headache, forgetfulness, and lack of focus.

Flowering and fruiting: Throughout the year

Description: An erect much-branched, under shrub, and pubescent. Leaves are elliptic-oblong, obtuse, or acute at apex, entire or serrate, pubescent, red, or purple small flowers. Nut-lets are not mucilaginous when wetted.

Botanical name: Origanum majorana L.

Synonyms: Majorana fragrans Raf., and Origanum salvifolium Roth.

Drug name: Origanum

English name: Sweet marjoram

Part used: Whole plant

Uses: Breastaffection of erotomania, hysteria, leukorrhea, nymphomania, seminal emission, and sexual irritation

Flowering and fruiting: June-September

Description: It is a bushy sub-shrub with aromatic foliage that typically grows in an upright mound to 1-2 cm tall. Features branching, reddish, and square stems that are densely clad with ovate, highly aromatic, pubescent, grey-green leaves. White or pink colors of flowers.

Botanical name: Origanum vulgare L.

Synonyms: O. americanum Raf. Origonum officinale Gueldenst.

Drug name: Origanum

English name: Wild marjoram

Part used: Whole plant

Uses: Breasts, affection, erotomania, leucorrhea, nymphomania, seminal emissions, and sexual irritation

Flowering and fruiting: June-September

Description: Perennial herb, growing from 20 to $80 \mathrm{~cm}$ tall, leaves is opposite and ovate shape, white or purple colors of flowers. Long, produced in erect spikes.

Botanical name: Perilla frutescens (L.) Britton.

Synonyms: Ocimum frutescens L., Perilla urticifolia Salisb.

Drug name: Perilla

English name: Beefsteak plant, Perilla, and wild coleus
Part used: Whole plant

Uses: Antioxidant, anti-allergic, anti-inflammatory, antidepressant, tumor-preventing property, gastrointestinal, dietary, and dermatology disease

Flowering and fruiting: August-October

Description: It is an erect annual herb with stem $0.3-2 \mathrm{~m}$ tall, densely hairy. Leaves are broadly ovate to round, green or purple, above hairy, below apprised hairy, margin coarsely saw toothed. Fruit nut-lets, and subglobose.

Botanical name: Plectranthus fruticosus L'Her.

Synonyms: Plectranthus urticifolia Lam., and Plectranthus arthropodus Briq.

Drug name: Plectranthus

German name: Gichtbaum

Part used: Whole Plant

Uses: Abdomen coldness of cholera, cramps, diarrhea, dysphagia, fever, intermittent fever, lumbrici, neuralgia, rheumatism, a throat, sore, and toothache.

Flowering and fruiting: February-April

Description: Native to South Africa. It is an erect evergreen undershrub with rounded hairy leaves thick spongy stem, spike of soft blue or mauve flowers, the inflorescence often 12 in long and very dense.

Botanical name: Plectranthus amboinicus Lour

Synonyms: Coleus aromaticus Benth., and Coleus amboinicus Lour.

Drug name: Coleus aromaticus

English name: Indian borage, Mexican mint; and Tam: Karpuravalli Part used: Leaf

Uses: Gonorrhea, urinary trouble, uremia, respiratory trouble, asthma, chronic, catarra, and epilepsy

Flowering and fruiting: December-March

Description: It is a succulent perennial herb usually aromatic, often fleshy, leaves opposite, flowers are on a short stem, pale purplish, in dense whorls (cymes) at distant intervals in a long slender spike-like raceme. Nut-lets smooth.

Botanical name: Plectranthus barbatus Benth.

Synonyms: Coleus forskohlii (Poir) Briq., and Coleus grandis L.H. Cramer Drug name: Coleus forskohlii.

English name: Indian coleus

Part used: Roots

Uses: Asthma, high blood pressure, blood clots, insomnia, dry eye, allergies, obesity, period pain, urinary tract infection, and bladder infection

Flowering and fruiting: October-December

Description: A perennial aromatic herb with branches from a thick rootstock, leaves fleshy, ovate or obovate, base narrowed margin cunate, apex obtuse, pubescent on both side gland dotted below, very softly-generally white-hairy, and the flowers whorls in blue color. Nutlets smooth dark brown.

Botanical name: Prunella vulgaris L.

Synonyms: Prunella cordata Raf., and Prunella longifolia Pers.

Drug name: P. vulgaris.

English name: Common self-heel, hook heel, and sickle wort

Part used: Whole plant

Uses: Allergies, anxiety stressful sleep, hemorrhoides, skin condition, travel sickness, cough, cold, and flu

Flowering and fruiting: June-October

Description: A herb with creeping rootstock, the stems and ovate obtuse leaves hispid, the corollas deep purple-blue or sometimes white, the bracts broadly ovate-cordate, apiculate often purple on the margins.

Botanical name: Rosmarinus officinalis L.

Synonyms: Rosmarinus angustifolius Mill., and Rosmarinus latifolius Mill.

Drug name: Rosmarinus.

English name: Rosemary

Part used: Whole plant 
Uses: Abortion, baldness, menses too early, dandruff, vertigo, and Miscarriage.

Flowering and Fruiting: March-October

Description: Native to Mediterranean region, it is an aromatic evergreen perennial herb with fragrant, needle-like leaves and white, pink, purple, or blue flowers.

Botanical name: Salvia officinalis L.

Synonyms: Salvia crespa Ten., and Salvia tricolor Vilm.

Drug name: S. officinalis

English name: Common sage

Part used: Fresh leaves, and blossom tips

Uses: Cough, tickling phthisis, night sweats, galactorrhea, and exerts a tonic influence on the skin

Flowering and fruiting: June-September

Description: Native to Mediterranean region, it is a perennial, evergreen sub-shrub with woody stems, greyish leaves, and blue to purplish flowers. Leaves are grey-green, rugose on the upper side, and nearly white underneath due to the many short soft hairs.

Botanical name: Salvia verbenaca L.

Synonyms: Sclarea verbenaca (L.) Sojak., and Gallitrichum verbenacum (L.) Fourr.

Drug name: Salvia.

English name: Wild clary, and wild sage

Part used: Whole plants

Uses: Removing small particles of dust from the eyes

Flowering and fruiting: June-September

Description: Native to Mediterranean region, it a tall perennial herb with hairy stems and branches that erectly sprawl out. Its leaves are basal and toothed that vary from 3 to $10 \mathrm{~cm}$. It has soft purple to violet flowers.

Botanical name: Thymus serpyllum $\mathrm{L}$

Synonyms: Origanum serpyllum (L.) Kuntze., and Thymus barbatus Opiz. Drug name: T. serpyllum.

English name: Wild thyme, and creeping thyme

Part used: Whole plant

Uses: Respiratory infection of children, dry nervous asthma, whooping cough, burning in pharynx, and sore

Flowering and fruiting: July-August

Description: North Europe it is perennial herb. The bright green leaves are slender or oval shaped. The root of this plant is fibrous and woody, while the stems are reddish-brown in color

Botanical name: Thymus vulgaris L.

Synonyms: Origanum thymus Kuntze., and Thymus chinensis K.Koch.

Drug name: Thymol

English name: Common thyme, and German thyme

Part used: Whole plant

Uses: Arthritis, bronchitis, colds, colic, cough, diarrhea, ear infection, flatulence, sore throat, and menstrual cramps

Flowering and fruiting: June-August

Description: Native to South Europe, it is a bushy, woody-based evergreen sub-shrub with small, highly aromatic, grey-green leaves and clusters of purple or pink flowers.

\section{CONCLUSION}

The present preliminary survey revealed that the Nilgiri district of Tamil Nadu (India) is rich in the diversity of medicinal flora used in the homeopathic system of medicine. This research study has provided documentation of 24 plants of Lamiaceae family that are of great medicinal value in the Nilgiri district. This is intended to provide information to the residents on the importance of such plant and how well they can use them in treating the common ailments that they encounter. Therefore, scientific cultivation, conservation, and sustainable utilization of plants by involving villagers would be highly beneficial in the conservation of these rare and endangered medicinally important species for the inheritance of this traditional knowledge to the coming generations.

\section{ACKNOWLEDGMENTS}

The authors are grateful to Dr. Anil Khurana, Director General In charge, Central Council Research in Homoeopathy, New Delhi, for the encouragement and providing necessary facilities for carrying out the work and authors also thankful to Dr. D. Suresh Baburaj, Scientist-4, (Retd.), CCRH, for valuable comments.

\section{AUTHORS' CONTRIBUTIONS}

S. Mugendhiran and M. Murali Surveyed and collected all the Homoeopathic medicinal plants belonging to Lamiaceae family, remaining authors coordinated the manuscript writing, editing, and finalization.

\section{CONFLICTS OF INTEREST}

The authors declare that there are no conflicts of interest regarding the publication of this paper.

\section{AUTHORS FUNDING}

The work has been completed as part of the regular Survey work of their research Unit as such no separate funds have been allotted for the present study.

\section{REFERENCES}

1. Ashvin VD, Mishra SH. In vitro antioxidant activity of an adaptogenic homeopathic formulation. Pharmacogn Mag 2007;3:124-9.

2. Ayensu ES. Medicinal Plants of West Africa. Algonac, Michigan: Reference Publication Inc.; 1978

3. World Wide Fund for Nature. Vital Wealth Plants. Gland, Switzerland: World Wide Fund for Nature; 1993.

4. Rajan S. Medicinal plants of Ootacamund, Tamil Nadu. J Econ Taxon Bot 1992;10:429-60.

5. Sultana A, Mukherjee SK. Usefulness of angiospermic plants in homoeopathy system of medicine. Int $\mathrm{J}$ Pharm Res BioSci 2015;4:291-309.

6. Hahnemann S, Devrient CH, Stratten S. The Homoeopathic Medical Doctrine or Organ One of the Healing Art. Sacramento, CA: Bulletin Solutions, Inc.;1833.

7. Ernst E. A systematic review of systematic reviews of homeopathy. $\mathrm{Br}$ J Clin Pharmacol 2002;54:577-82.

8. Jonas WB, Kaptchuk TJ, Linde K. A critical overview of homeopathy. Ann Intern Med 2003;138:393-9.

9. Iwalokun BA, Gbenle GO, Adewole TA, Smith SI, Akinsinde KA, Omonigbehin EO. Effects of Ocimum gratissimum L essential oil at subinhibitory concentrations on virulent and multidrug-resistant Shigella strains from Lagos, Nigeria. APMIS 2003;111:477-82.

10. Sarac N, Ugur A. Antimicrobial activities and usage in folkloric medicine of some Lamiaceae species growing in Mugla, Turkey. Eurasian J Biosci 2007;4:28-37.

11. Haq N. In vitro Production of Bioactive Compounds from Medicinal Plants. Proceedings of the Meeting Held at the Plant Genetic Resource Institute. Pakistan, Islamabad: Agricultural Research Council; 1998.

12. Matkowski A, Szypula E, Tasarz P. Antioxidant activity of herb extracts from five medicinal plants from Lamiaceae, subfamily Lamioideae. J Med Plant Res 2008;2:321-30.

13. Roy S, Awasthi H. Herbal medicines as neuroprotective agent: A mechanistic approach. Int J Pharm Pharm Sci 2017;9:1-7.

14. Uritu CM, Mihai CT, Stanciu G, Dodi G, Alexa-Stratulat T, Luca A, et al. Medicinal plants of the family Lamiaceae in pain therapy: A review. Pain Res Manag 2018;2018:1-44

15. Logesh R, Dhanabal SP, Duraiswamy B, Chaitanya MV, Dhamodaran P, Rajan S. Medicinal plants diversity and their folklore uses by the tribes of Nilgiri Hills, Tamil Nadu, India. Int J Pharmacogn Chin Med 2017:1:1-14.

16. Jain SK, Roa RR. Handbook of Field and Herbarium Methods. New Delhi: Today and Tomorrow Printers \& Publishers; 1976.

17. Gamble JS, Fischer CE. Flora of the Presidency of Madras. London: AJ Lord and Sons Limited; 1915-1935. p. 1-3.

18. Fysen PF. The Flora of the South Indian Hill Station. Chennai: Superintendent, Government Press; 1915-1920. p. 78-93.

19. Nair NC, Henry AN. Flora of Tamil Nadu series 1: Analysis Vol. 1. Botanical survey of India, Howrah. Nature 1983;446:1079-81. 
20. Mathew KM. The exotic flora of Kodaikanal, Palni hills. Rec Bot Surv India 1969;20:1-241.

21. Mathew KM. The Flora of the Tamil Nadu Carnatic. Tiruchirappalli: The Rapinat Herbarium, St. Joseph's College; 1983. p. 3.

22. Sharma BD, Shetty BV, Vajravelu E, Kumari GR, Vivekanthan K, Chndrabose M, et al. Studies on the flora of Nilgiris, Tamil Nadu. Bio Mem 1977;2:1-86.

23. Sharma BD, Shetty BV, Vajravelu E, Kumari GR, Vivekanthan K, Chndrabose M, et al. Flora of Mudumalai Wild Life Sanctuary, Tamil Nadu. J Bombay Nat Hist Soc 1977;75:13-42.

24. Bailey LH. Manual Cultivated Plants: Most Commonly Grown in the Continental United State and Canada. New York: The Macmillan Company; 1949.

25. Boericke W. Pocket Manual of Homoeopathic Materia Medica. New Delhi: B. Jain Publishers; 1988.

26. Clarke JH. Dictionary of Practical Materia Medica. New Delhi: B. Jain Publishing Company; 1982.

27. Allen TF. The Encyclopedic of Pure Materia Medica. New Delhi: B. Jain Publishers; 1982.

28. Blackwood AL. A Manual of Materia Medica, Therapeutics and pharmacology. New Delhi: World Homoeopathic Links; 1906.
29. Wren RC. Potter's New Cyclopaedia of Botanical Drugs and Preparations. New Delhi: Jain Publishing Company; 1983.

30. Hamilton E. Flora Homeopathic or Illustrations and Descriptions of the Medicinal Plants used as Homoepathic Remedies. New Delhi: B. Jain Publishers; 1982

31. Baburaj DS, Rajan S, Sethuraman M. Additional to the checklist of homoeopathic medicinal plants of India. CCRH Q Bull 1992;14:1-2.

32. Singh H. Hand Book on Herbaria in India and Neighbouring Countries. New Delhi: National Institute of Science Communication and Information Resources, CSIR; 2010.

33. Dash B, Junius MM. A Hand Book of Ayurveda. New Delhi: Concept Publishing Company; 1983.

34. Gopal GV, Shah GL. Some folk medicinal plants used for jaundice in Gujarat, India. J Res Educ Indian Med 1985;4:45-58.

35. Jain SK. Dictionary of Indian Folk Medicine and Ethno-botany. New Delhi: Deep Publication; 1991. p. 311

36. Sivarajan VV, Balachandran I. Ayurvedic Drugs and their Plant Source. New Delhi: Oxford and IBH Publishing Company Pvt.; 1994. p. 570.

37. Kumar A, Dimple, Kumar V, Tomer V. Traditional medicinal systems for treatment of diabetes mellitus: A review. Int J Pharm Pharm Sci 2018;10:7-17. 